\title{
Comparison of the sensitivity and specifity of modified Rose Bengal and ELISA test in the diagnosis of brucellosis
}

\author{
Behrooz Halashi ${ }^{1}$, Hanieh Tarokhian ${ }^{2}$, Babak Sayad ${ }^{3}$, Garhad Salari $^{2}$, Ali Gorgin Karaji ${ }^{4}$ \\ 1. MSc, Emam Reza Hospital, School of Medicine, Kermanshah University of Medical Sciences, Kermanshah, Iran. ORCID \\ ID: 0000-0002-0360-7217 \\ 2.Assistant Professor, Department of Immunology, School of Medicine, Kermanshah University of Medical Sciences, \\ Kermanshah, Iran. Tarokhian ORCID ID: 0000-0001-8920-6352, Salary ORCID ID: 0000-0003-3211-0354 \\ 3.Professor,Department of Infectious Disease, School of Medicine, Kermanshah University of Medical Sciences, \\ Kermanshah, Iran. ORCID ID: 0000-0001-8686-9986 \\ 4. Associate Professor, Department of Immunology, School of Medicine, Kermanshah University of Medical Sciences, \\ Kermanshah, Iran., (Corresponding Author), Tel: 083-34274618-20, Email: a_gorginkaraji@kums.ac.ir, ORCID ID: 0000- \\ 0003-4537-5722
}

\begin{abstract}
Background and Aim: Brucellosis is a zoonotic disease and is one of the major health problems in our country. Considering its nonspecific symptoms, diagnosis of this disease is often made by laboratory methods. The purpose of the present study was to compare the sensitivity and specificity of ELISA and a relatively new modified Rose Bengal test in the diagnosis of brucellosis.

Material and Methods: In this cross-sectional study, blood samples were taken from 162 patients who had been diagnosed by an infectious disease specialist as suspected brucellosis. We used clot tube for serum preparation and anticoagulant tube to prevent coagualation. Serum was used for modified Rose Bengal test and ELISA tests and blood with anticoagulant was used for PCR test, as a gold standard test.

Results: The results of this study showed that modified Rose Bengal test had high sensitivity $(94 \%)$ and relatively good specificity (70\%), compared to PCR. In addition, ELISA test for IgG specific to Brucella antigen also had the same sensitivity and specificity as the modified Rose Bengal test (sensitivity $94 \%$ and specificity $71 \%$ ). In contrast, ELISA test for IgM specific to Brucella antigen, showed high (84\%) specificity, but low (65\%) sensitivity.

Conclusion: The results of this study showed that the sensitivity and specificity of the modified Rose Bengal test were similar to those of ELISA test for IgG and could be a good alternative to this expensive and complex test in the diagnosis of brucellosis.
\end{abstract}

Keywords: Modified rose Bengal, IgG ELISA, IgM ELISA, Polymerase chain reaction

Received: Aug 5, $2019 \quad$ Accepted: Nov 11, 2019

How to cite the article: Behrooz Halashi, Hanieh Tarokhian, Babak Sayad, Farhad Salari, Ali Gorgin Karaji. A Comparative Study of the Sensitivity and Specificity of the Modified Rose Bengal Test and the ELISA Test in the Diagnosis of Brucellosis. SJKU 2020;25(3):1-13.

Copyright (C) 2018 the Author (s). Published by Kurdistan University of Medical Sciences. This is an open access article distributed under the terms of the Creative Commons Attribution-Non Commercial License 4.0 (CCBYNC), where it is permissible to download, share, remix, transform, and buildup the work provided it is properly cited. The work cannot be used commercially without permission from the journal 
بررسى مقايسهاى حساسيت و ويخىى آزمايش رزبنكال اصلاح شده و آزمايش الايزا در تشخيص بيمارى بروسلوز

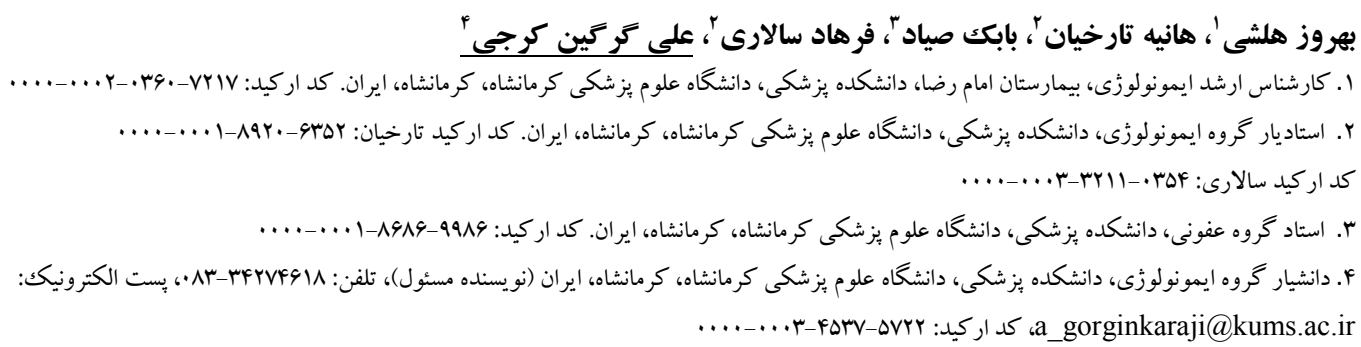

جكيده

زمينه و هدف: بروسلوز يكك بيمارى زئونوز است و از مشكلات بهداشتى مهم كشور محسوب مىشود. تشخيص اين بيمارى، به

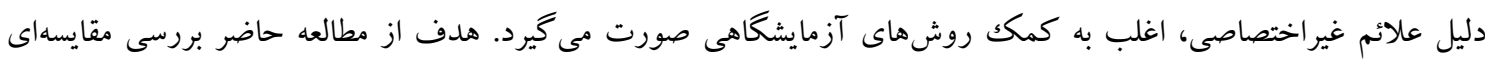

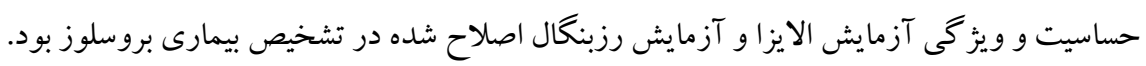

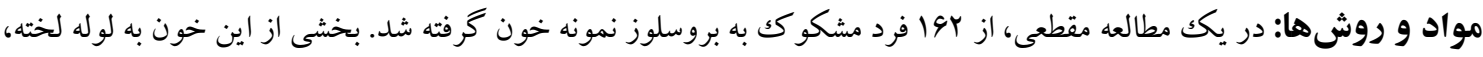
جهت تهيه سرم و بخش ديخر به لوله واجد ضد انعقاد منتقل شد. سرم جهت انجام آزمايش رزبنكال اصلاح شده و و آزمايش الايزا

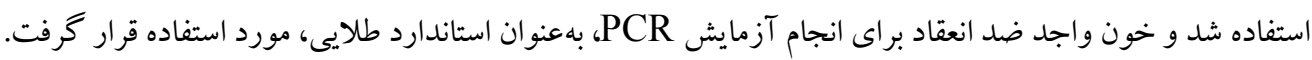

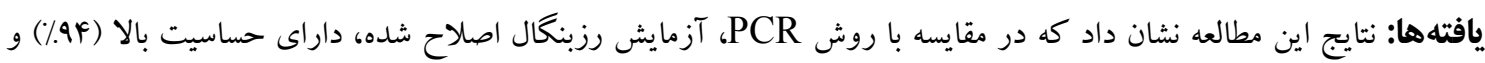

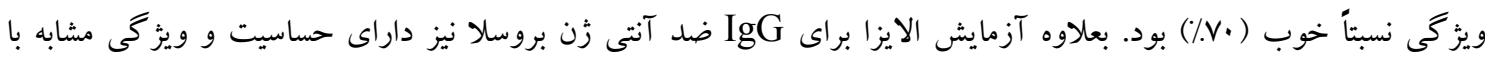

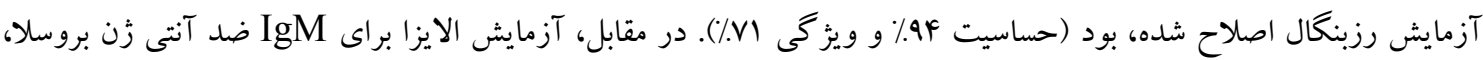

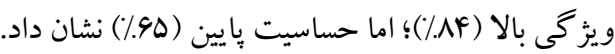

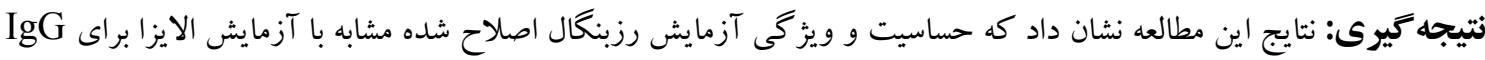

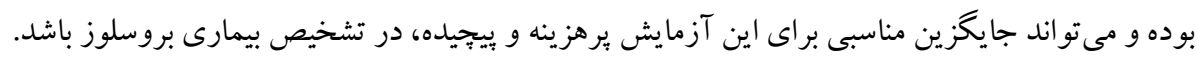

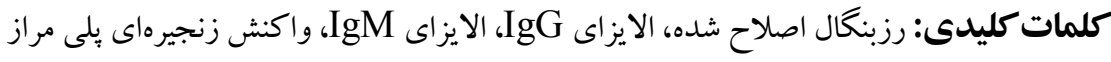

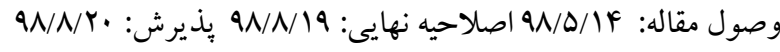


نسبت به رزبنگال معمـولى دارد( (11). از طرف ديخر، روش الايزا به عنوان يكك آزمايش با حساسيت بالا شناخته مىشـود

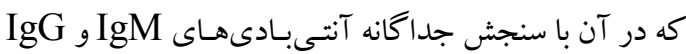

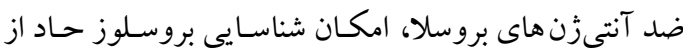

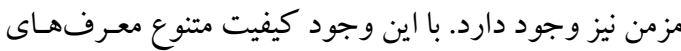

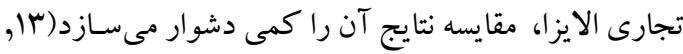

.(Ir

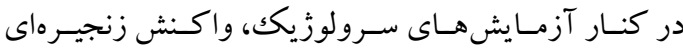
يليمراز (PCR)، بهواسطه توانايى تشخيص مقادير بسيار كمى

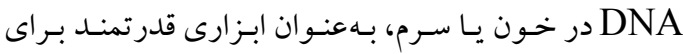
تشـخيص بيمـارى بروسـلوز محسـوب مسىشـود (Q)

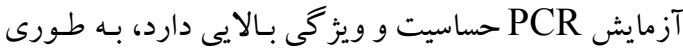
كه از كشت خون حساستر بوده و نسبت بـه آزمايشهـاى متــاول ســرولوزيكك ويز خـى بـالاترى دارد (9) ). بـه دليـل

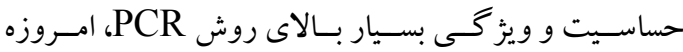
متخصصين زيادى بيشنهاد مى كنند كه به جاى كشت خـون،

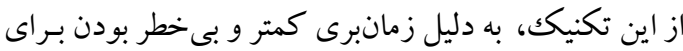
كار كنـان آزمايشـاها، بــعنـوان استاندارد طلايسى اسـفاده

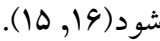
نظـر بـه اينكـه مطالعـات اخيـر حـاكى از حساسـيت بـالاى آزمايش رزبنكال اصلاح شده در تشخيص بيمارى بروسلوز است، بعلاوه الايزا نيز بهعنوان يكك آزمايش بـا حساسيت و

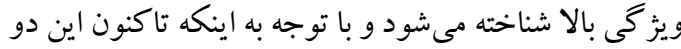

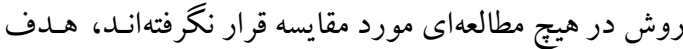
از تحقيق حاضـر مقايسه حساسيت و ويزگ كى ايـن دو روش آزمـايش در تشـخيص بيمـارى بروسـلوز، در حضـور روش واكنش زنجيرهاى يلى مـراز (PCR)، بـهنـوان استاندارد

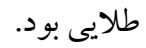

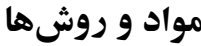

نمونه كيرى

در يكك مطالعه مقطعى كه از فروردين اaجا شروع شده و تا

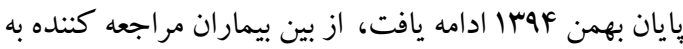

مقدمه

بيمارى بروسلوز كه بهعنوان (تب مواج)، (اتب مديترانه ای)" يا (تب مالت) نيز شناخته مى شود، توسط باكترى هـاى جـنس بروسلا ايجـاد مسىود (1). ايـن بيمارى، در انسان، در اثر تماس مستقيم يا غيرمستقيم با حيوانات آلوده يـا محصولات لئات آن ها و يا مصرف لبنيات غيرياستوريزه ايجاد مىشود (آ, Y).

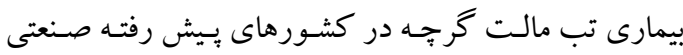
ريشه كن شدهاست؛ اما در خاورميانه (از جمله ايـران)، هند،

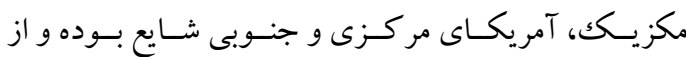

مشكلات مهم بهداشتى در اين كشورها بشمار مىرود(f).

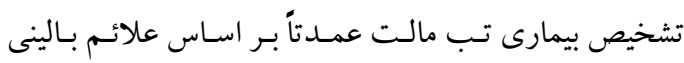

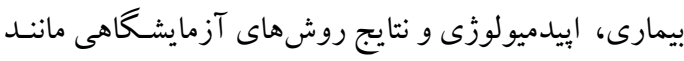

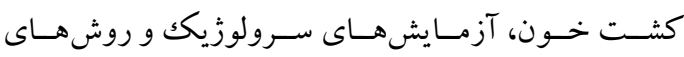

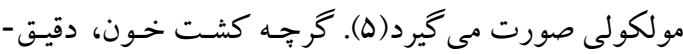
ترين و معتبرترين روش تشخيص بيمارى محسوب مسى شـود؛ اما در عمل خيلى كـم مثبـت مـى شـود، بعلاوه خطر انتقال بيمارى به كار كنان آزمايشكاه را نيز در بر دارد (9)؛ بنابر اين،

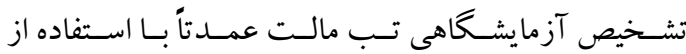

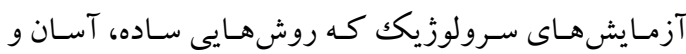

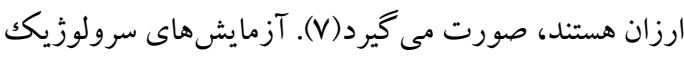

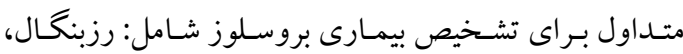

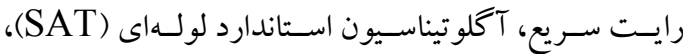

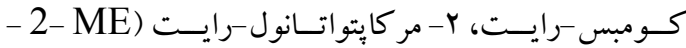
رايت)، فيكساسيون كميلمان، ايمنوفلورسـانس غيرمستقيم و

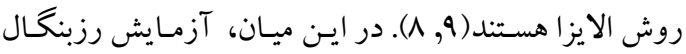

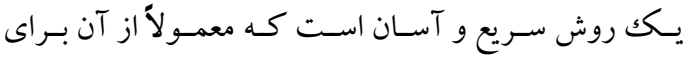
غربال گرى نمونه سرمها و تعيين نمونسهـاى مثبـت است، استفاده

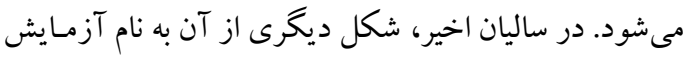

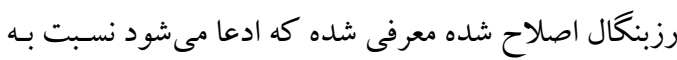

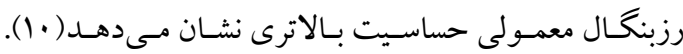
بررسىها حاكى است، اين روش كه اولين بار در سال 1994 توسط بلاسكو و همكاران شرح داده شد، حساسيت بـالاترى 
بر روى نمونه خــون واجــ ضـــ انعقـاد ايـن افر اد، آزمـايش PCR بهنوان آزمايش اسـتاندارد طلايسى، بـراى تشـخيص وجود DNA باكترىهاى جنس بروسلا انجام شد.

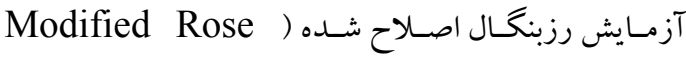
(Bengal test معمولى است كه در آن بجاى مجاور شدن يكك حجـم سـرم بيمار با حجم معادل از آنتىزن بروسلا، سه حجم سـرم بيمـار با يكك حجم آنتىزن بروسلا مجاور مى شود. براى اين منظور

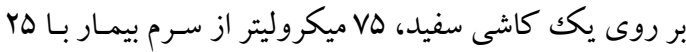
ميكروليتـر از سوسيانسـون آنتىزن مجـاور كـرده و يسـ از مخلوط كردن، به مدت F مقيقـه حركت دورانسى داده شـد. بس از مدت زمان فوق نمونـه از نظر آكلو تيناسـيون بررسى شد، جنانجه آكلو تيناسـيون واضـح مشـاهده مسى شــد، نتيجـهـ آزمايش مثبت در نظر كرفته مسىشـد، در غيـر ايسن صسورت نتيجه منفى در نظر كرفته مى شد. آزمـايش رزبنگگال اصـلاح

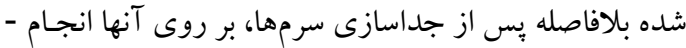
شد؛ اما براى انجام آزمايش الايزا نمونه سرمها تا زمان انجـام

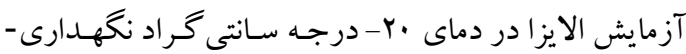
شدند. بِ از استخراج، DNA نيز تازمـان انجـام آزمـايش

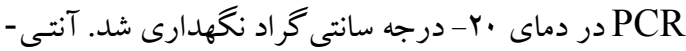
زن رزبنگًال مورد استفاده در ايـن مطالعـه از انستيتيو ياسـتور ايران تهيه گر ديد.

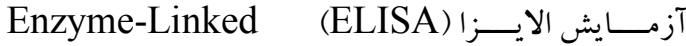
T. Immunosorbent Assay

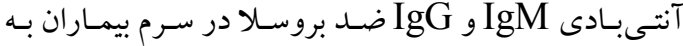

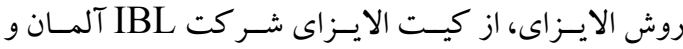
دستخاه ميكرويليت ريـدر مــل Stat Fax 4200 اسـتفاده

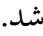

استخراج DNA extraction)DNA): در ايسن مطالعه، بــراى اسـتخراج DNA از نمونسه خــون بيمـاران، از كيـت استخراج GeneAll) DNA، كره جنـوبى) اسـتفاده شـد. همجِنين DNA مورد نياز جهت كنترل مثبت، از كلنىهـاى
مطــب بز شـكك متخصــص عفـونى، واقـع در مركـز شـهر كرمانشاه، يس از معاينه، آنهايى كه واجد حداقل دو مـورد

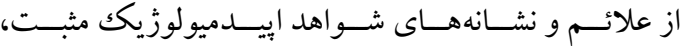
ار كانومخـالى، آرتريست، آرترالـزى و تسب بودنـد، توسـط يزشك مربوطه مشكو كك به بروسـلوز تشـخيص داده شــده و جهت انجام آزمايش هاى تشخيصى معرفى شدند. بـر اسـاس مطالعات قبلى حجم نمونه •91 نفر تعيـين شـد(19, ه1) و در

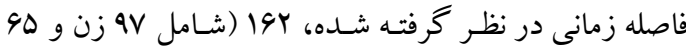
مرد) فرد مشـكو كك بـه بروسـلوز وارد مطالعـه شــند. از ايـن

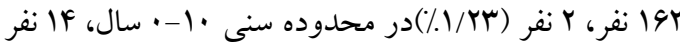

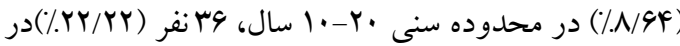

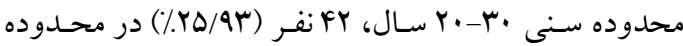

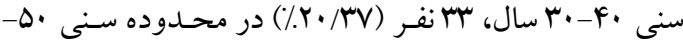

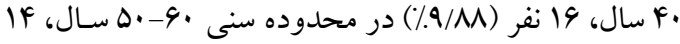

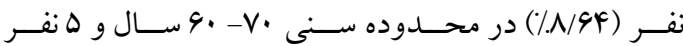

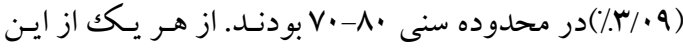

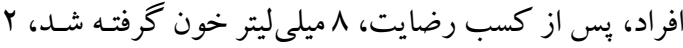
ميلىليتر آن براى انجام آزمـايش PCR بـه لوله واجـد ضــ

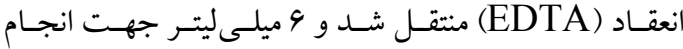
آزمايش رزبنگًال اصلاحشده و الايزا به لوله لخته منتقل شد. معيار خروج از مطالعه ابتلا به بيمـارىهـاى التهابى و عفـونى ديخر بود كه به تشخيص بزشكك متخصص عفونى از مطالعه كنار كذاشته شدند و تنها بيمـارانى كـهـ بـر اسـاس شـواهد و علائم بالينى مشكو كك به بيمارى بروسلوز بودند وارد مطالعه شدند. بيمار ان فرم رضايتنامـه را مطالعـه و امضـاء كردنـــ و اطلاعات آنها كاملاً محر مانه نگخاه داشته شد و بـهـ هـر بيمـار يك كد داده شد.

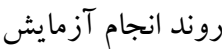
بـر روى نمونسه سـرم تمـام بيمـاران مشـكو كك بـه بروسـلوز، آزمايش رزبنگال اصلاح شده و آزمايش الايزا بـراى آنتى -

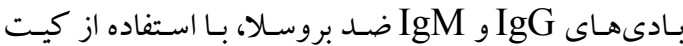
تشخيصى الايزاى شركت IBL آلمان، انجام شـد. همجنـين 
حساسيت و ويزگى و ارزش اخبارى مثبت و منفى آزمايش-

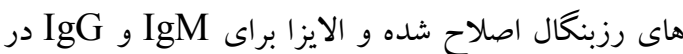
مقايسه با آزمايش PCR (استاندارد طلايى) سنجش شد.

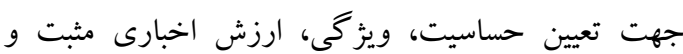
ارزش اخبارى منفى آزمايشها، از فرمولهاى زير استفاده

شد:

تعداد موارد مثبت حقيقى + تعداد موارد منفى كاذب/ تعـداد

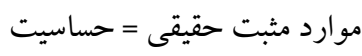

تعداد موارد منفى حقيقى + تعداد موارد مثبت كاذب / تعداد

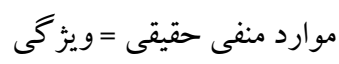

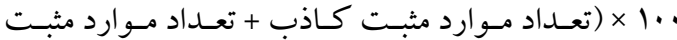

حقيقى / تعداد موارد مثبت حقيقى) = ارزش اخبارى مثبت

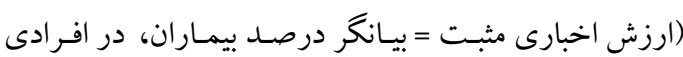
است كه نتيجه آزمايش آنها مثبت بودهاست.)

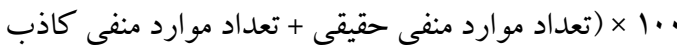
( تعداد موارد منفى حقيقى) = ارزش اخبارى منفى

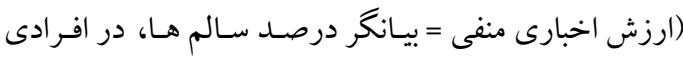
است كه نتيجه آزمايش آنها منفى بودهاست.

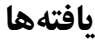
نتايج اين مطالعه نشان داد كه زنان، بـه دليـل تمـاس بيشتر بـا

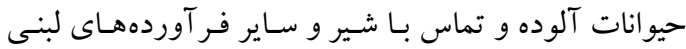
بيشتر در معرض ابتلا به اين بيمارى هستند، به همين دليل در اين مطالعه تعداد زنان بيمار بيش از مردان بود. همجنين بيشتر

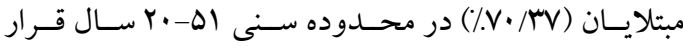

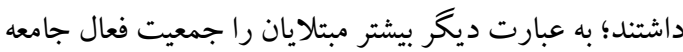

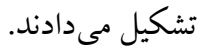
نتايج PCR: آزمايش PCR بر روى نمونه خون بول 19 بيمار مشكو كك به بروسلوز انجام گرديد. از اين آزمايش بـهنوان

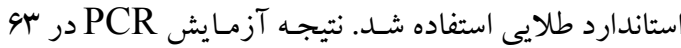
مورد (9\%/) مثبت و در 99 مورد (191/) منفى شد.

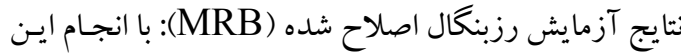

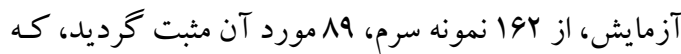

بـاكترى بروسـلا (تهيـه شــده از انسـتيتو ياسـتور)، اسـتخراج كرديد.

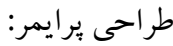

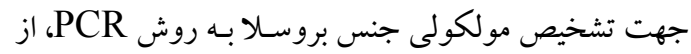

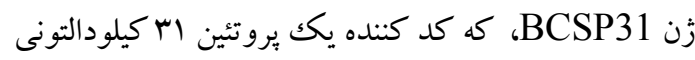

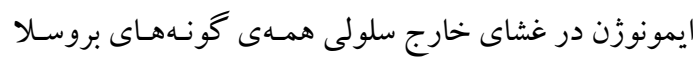

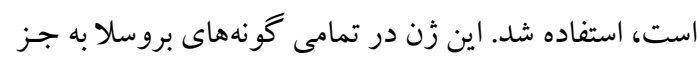

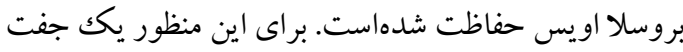
ير ايمر طراحى شد (جـدول (). بـراى طراحسى برايمـر از نرم

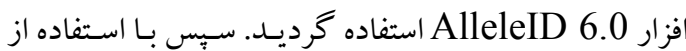
برنامه BLAST اتصال برايمرهـا بـه تـوالى مربوطه و سـاير

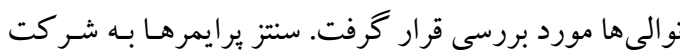
ماكروزن كره جنوبى سفارش داده شد. واكسنش زنجيره اى يلى مـراز ( Polymerase (PCR) تمل استخر اج شده از نمونه خون DNA :Chain Reaction تمامى افراد، هدف آزمايش PCR قرار گرفت. بـراى انجام

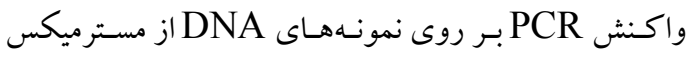
شر كت سينا كلون استفاده شد و واكنش با استفاده از دستكاه ترمو سايكلر (Bio- RAD مدل C1000) Touch) انجام ولينام

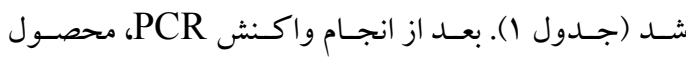

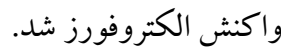
تجزيه و تحليل آمارى نتايج به دست آمده از آزمايشهـاى مـورد استفاده در ايـن مطالعه، با استفاده از نرم افزار SPSS نسخه 19 مورد تجزيـه

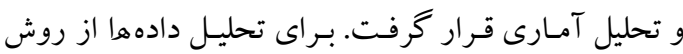

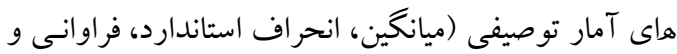

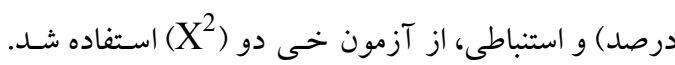
براى دادههاى كيفى، آزمون تحليل واريـانس يـكراهـه و

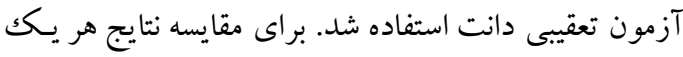

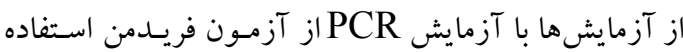
شد. همجنين براى ميزان همانندى بين آزمايشهاى مختلف

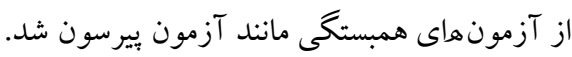


بودن فرد بيشتر اسـت (جـدول 9). حساسـيت و ويزگى ايـن

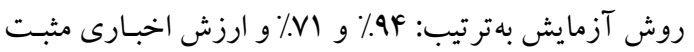
و منفى آن بهترتيب: 9V\% و 9 \% \% بود.

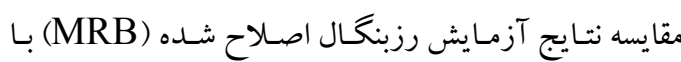
الايز IgM: مقايسه نتايج اين دو نوع آزمايش در نمونه سرم فر اد مشكو كك به بروسلوز نشان داد كـه تعـداد مـواردى كـه هم نتيجه آزمايش MRB در آن ها مثبت شده و هـم مقـدار آنتىبادى IgM آنها بيشتر از · ا واحد بـود، ·ه مـورد بـود كه هو مورد آنها PCR مثبت بودند. از طرف ديخر تعـداد مواردى كه نتيجه الايـزاى IgM در آنهـا منفـى شـد؛ ولى آزمايش رزبنگال اصلاح شده آنها مثبت گرديد، هب مـورد بـود كـه · ب مـورد از آنهـا PCR مثبـت بودنسـ. در مقابـل، تعداد مواردى كه سطح IgM آنها بيشتر از ده واحد بـوده؛ ولى نتيجه آزمايش رزبنگًال اصلاح شده در آن ها منفى شده

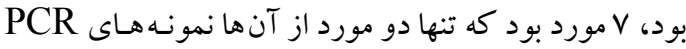

$$
\text { مثبت بودند (جدول V). }
$$

مقايسه نتـايج آزمـايش رزبنكـال اصـلاح شـده (MRB) بـا الايزا IgG: مقايسه نتايج آزمايش رزبنگكال اصـلاح شـده بـا

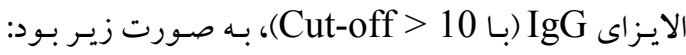
تعداد مواردى كه هـم نتيجـه آزمـايش MRB آنهـا مثبـت بود و هم سطح IgG آنها بيشتر از · ا واحد بـود، V9 مـورد بود كه هV مورد آنها نمونه هاى PCR مثبـت بودنـد. تعـداد IgG آنها مثبـت بـود؛ امـا سـطح آن ها كمتر از ·ل واحد بود، سا مورد بود كـه تنها دو مـورد از آن ها PCR مثبت بودند. به طور مشابه تعداد مـواردى كـه مقدار آنتى بـادى IgG آنهـا بيشـتر از •ا واحسد بـود؛ ولى نتيجه آزمايش MRB آنها منفى بود، Yا مورد بـود كه دو مورد از آنها PCR مثبت بودند (جدول ^).
هه مــورد از سو مــورد مثبـت شــده بـا روش PCR (كلــ استاندارد) را بوشش مى داد؛ بنـابراين، در ايـن آزمـايش، ·ـ مـورد مثبـت كـاذب و F مـورد منفى كـاذب وجـود داشـت (جدول r). حساسيت و ويزز گى ايسن آزمايش بـه شـرح زيـر

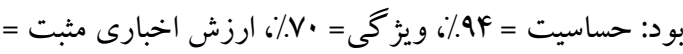
94\% و ارزش اخبارى منفى آن = هـ٪ بود.

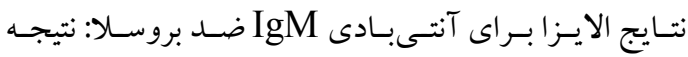
آزمايش الايزا براى آنتىبادى IgM ضد آنتىزن بروسلا در هV نمونه از Y9 ا نمونه سرم) مثبت شد (سطح آنتىبـادى در

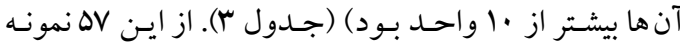
مثبت شده از نظر آنتىبادى IgM ضد آنتىزن بروسلا، تنها

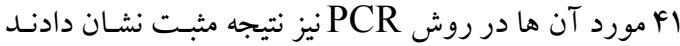
(جدول (). حساسيت و ويثز گى اين آزمايش به ترتيـب: 90\% و و بود و ارزش اخبارى مثبت و منفى آن بـهترتيـب: VY

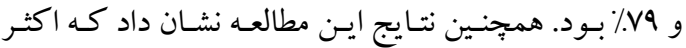
نمونههايى كه نتيجه آزمايش PCR در آنها مثبت گررديـد، داراى تيتر آنتىىبـادى IgM ضـد بروسـلا يـايين، حتى تيتـر

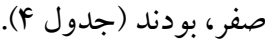
نتايج الايـزاى آنتسىبـادى IgG ضـــ بروسـلا: بـا انجـام ايـن

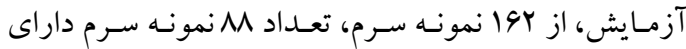
سطح آنتىبادى IgG بيشتر از • ا واحد بودند، بنابراين مثبت در نظر گرفته شدند (جدول ه). از اين \M نمونه سـرم مثبـت، هو مورد آنها در روش PCR نيز نتيجه مثبت نشـان دادنـد؛ امـا نتيجـه آزمـايش PCR در هو نمونـه سـرم منفـى شــــ از

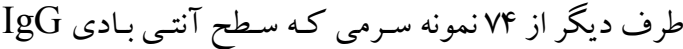
آنهـا كمتـر از ·ل واحسد بـود، نتيجـه آزمـايش PCR در F نمونه سرم مثبت شد (منفى كاذب). همجنين نتايج نشـان داد كه هر جֶه تيتر آنتىبـادى IgG بـالاتر باشـد، احتمـال بيمـار 
جدول ا. جدول زمان بندى دمايى واكنش PCR و توالى يرايمرهاى مورد استفاده در واكنش

\begin{tabular}{|c|c|c|c|c|c|c|}
\hline كسترش نهايى & تعداد سيكل & اكستنشن (كسترش) & 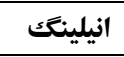 & دناتوراسيون & دناتوراسيون اوليه & \\
\hline Vr & r. & VY & 90 & 90 & 90 & سانتى (درجراد) \\
\hline 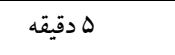 & & 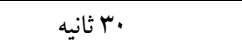 & 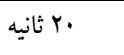 & 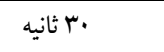 & 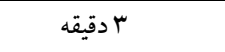 & زمان \\
\hline جفت باز) & & & & & & ير ايمر \\
\hline \multirow{2}{*}{\multicolumn{2}{|c|}{ 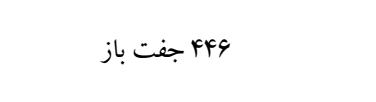 }} & \multicolumn{4}{|c|}{ 5'-TCC GAT TGG TGG TCT GAT C-3' } & فوروارد \\
\hline & & \multicolumn{4}{|c|}{ 5'-CAC CAT CTT TCA GCC TCT C-3' } & معكوس \\
\hline
\end{tabular}

جدول r. حساسيت و ويزگى آزمايش رز بنغال اصلاح شده (MRB) درمقايسه با PCR

\begin{tabular}{|c|c|c|c|c|}
\hline \multirow[t]{2}{*}{ جمع } & \multicolumn{4}{|c|}{ آزمايش رز بنكال اصلاح شده } \\
\hline & مثبت & منفى & & \multirow{3}{*}{ آزمايشPCR } \\
\hline 99 & $r$. & 99 & منفى & \\
\hline gr & $\Delta q$ & f & مثبت & \\
\hline 195 & 19 & vr & & جمع \\
\hline
\end{tabular}

جدول س. حساسيت و ويزگى آزمايش الايزاى IgM در مقايسه با PCR

\begin{tabular}{|c|c|c|c|c|}
\hline \multirow[t]{2}{*}{ جمع } & \multicolumn{2}{|c|}{ IgM I آزمايش الايزا } & & \\
\hline & مثبت & منفى & & \multirow{3}{*}{ آزمايش PCR } \\
\hline 99 & 19 & $\wedge r$ & منفى & \\
\hline $4 r$ & \&1 & ry & مثبت & \\
\hline 194 & $\Delta V$ & $1 \cdot 0$ & & جمع \\
\hline
\end{tabular}

جدول f. رابطه تيتر آنتىبادى در الايزاى IgM با نتيجه آزمايش PCR

\begin{tabular}{|c|c|c|c|c|c|c|}
\hline$r \cdot \cdot-r \Delta$. & $10 \cdot-r \cdot \cdot$ & $1 \cdots-10$ & $0 \cdot-1 \ldots$ & $1 \cdot-\Delta \cdot$ & $\cdot-1$ & تيتر IgM \\
\hline & & 9 & if & rv & 1.0 & تعداد نمونه سرم \\
\hline & & 9 & Ir & r & rr & تعداد PCR مثبت \\
\hline
\end{tabular}


جدول ه. حساسيت و ويزّى آزمايش الايزاى IgG در مقايسه با PCR

\begin{tabular}{|c|c|c|c|c|c|}
\hline \multirow{4}{*}{ ارتباط تيتر } & \multirow[t]{2}{*}{ جمع } & \multicolumn{2}{|c|}{ IgM تيتر 10IU } & & \multirow[b]{3}{*}{ آزمايش PCR } \\
\hline & & مثبت & منفى & & \\
\hline & 99 & rq & v. & منفى & \\
\hline & $9 \pi$ & $\Delta q$ & F & مثبت & \\
\hline در الايزاى & 194 & $M$ & $V_{F}$ & & جمع \\
\hline
\end{tabular}

\begin{tabular}{|c|c|c|c|c|c|c|c|c|}
\hline$>r \ldots$ & $r \Delta \cdot-r .$. & $r \cdots-r \Delta$. & $10 \cdot-r \cdot$. & $1 \cdots-10$ & $\Delta \cdot-1 \cdot$. & $1 \cdot-\Delta \cdot$ & $\cdot-1$. & IgG تيتر \\
\hline$\checkmark$ & r & r & 11 & ro & ir & 19 & $V^{F}$ & تعداد نمونه سرم \\
\hline 9 & r & $r$ & 11 & IV & 11 & $r$ & F & تعداد PCR مثبت \\
\hline
\end{tabular}

IgM در مقايسه با PCR IgM

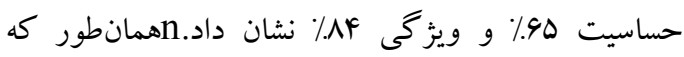
جدول نشان مىدهد اكثر نمونههايى كه نتيجه آزمايش

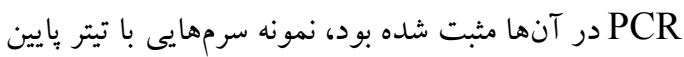
و حتى تيتر صفر آنتىبادى IgM ضد بروسلا بودند. نتيجه بررسى نمونه سرمهاى افراد مشكو كك به بروسلوز با آزمايش لاي

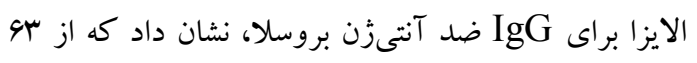

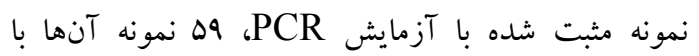
آزمايش الايزاى IgG نيز مثبت شدند؛ اما م نمونه سرم منفى كاذب شد، بعلاوه qج نمونه سرم نيز مثبت كاذب شد. به اين ترتيب آزمايش الايزاى IgG در مقايسه با PCR

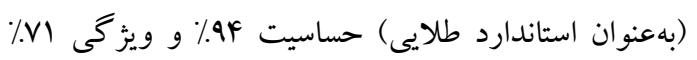
نشان داد. نتايج مطالعه نشان داد كه ارتباط مستقيمى بين تيتر آنتىبادى IgG و مثبت شدن نتيجه آزمايش PCR وجود دارد، هر جقدر تيتر آنتىبادى IgG بالاتر باشد، احتمال

$$
\text { مثبت شدن آزمايش PCR بيشتر است. }
$$

با بررسى نمونه سرمهاى افراد مشكوكك به بروسلوز با

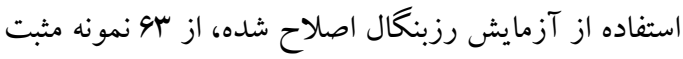
شده با آزمايش PCR، هوه نمونه مثبت شد؛ اما ث نمونه سرم بهورت كاذب منفى شد، بعلاوه ·r نمونه سرم نيز به صورت كاذب مثبت شد. به اين ترتيب آزمايش MRB در

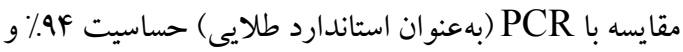

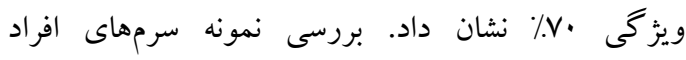

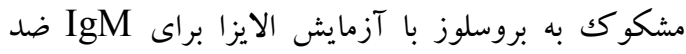
آنتىزن بروسلا، نشان داد كه از سو نمونه مثبت شده با آزمايش PCR، أFمونه سرم واجد تيتر آنتىبادى IgM ضد آنتى زُنهاى بروسلا بيشتر از ·ل واحد (مثبت) بود؛ اما در Y ب نمونه سرم تيتر آنتىبادى IgM ضد آنتىزن بروسلا كمتر از •ا واحد بود (منفى كاذب)، بعلاوه 19 نمونه سرم نيز در حاليكه نتيجه آزمايش PCR آنها منفى بود، تيتر

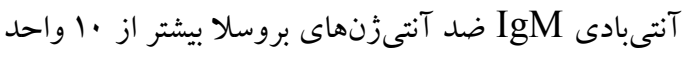
نشان دادند (مثبت كاذب). به اين ترتيب آزمايش الايزاى 


\section{جدول Y. مقايسه نتايج آزمايش رزبنكال اصلاح شده (MRB) با الايزاى IgM ضد آنتىخن بروسلا}

\begin{tabular}{|c|c|c|c|c|}
\hline \multirow[t]{2}{*}{ جمع } & \multicolumn{2}{|c|}{ IgM ت 10IU } & & \multirow[b]{3}{*}{ آزمايش MRB } \\
\hline & مثبت & منفى & & \\
\hline$v r$ & $v$ & 99 & منفى & \\
\hline$\wedge 9$ & $\Delta$. & $r q$ & مثبت & \\
\hline 194 & $\Delta V$ & 1.0 & & جمع \\
\hline
\end{tabular}

IgM

سرم افر اد مشكو كك به بروسلوز با اين دو نوع آزمايش نشان

منفى شد؛ ولى آزمايش رزبنگال اصلاح شده آنها مثبت داد كه •ه نمونه سرم با هر دو آزمايش MRB و الايزاى آزمايش آلايزاى IgM در آنها مثبت شد؛ولى آزمايش مثبت شدند و نتيجه 99 نمونه سرم با هر دو آزمايش تهر رزبنگال اصلاح شده آنها منفى گرديد، V مورد بود.

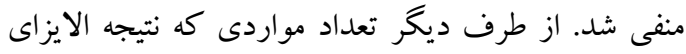

جدول ^. مقايسه نتايج تست رزبنكال اصلاح شده (MRB) با الايزاى IgG ضد آنتىثن بروسلا

\begin{tabular}{|c|c|c|c|c|}
\hline \multirow[t]{2}{*}{ 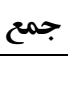 } & \multicolumn{2}{|c|}{ IgG تيتر 10IU } & & \\
\hline & مثبت & منفى & & \multirow{3}{*}{ آزمايش MRB } \\
\hline$v r$ & ir & 91 & منفى & \\
\hline$\wedge 9$ & va & ir & مثبت & \\
\hline 194 & M & $v^{F}$ & & جمع \\
\hline
\end{tabular}

تشـخيص بيمـارى بروسـلوز برخـوردار اسـت (1). همجنـين آزمايش الايسزا نيـز بـهــــوان يـك آزمـايش بـا حساسـيت و ويز گى بالا شناخته مسىشـود. از طرف ديخـر، در مطالعـات كذشته روش PCR، به دليل ايمنى بالا، حساسيت و ويزگى

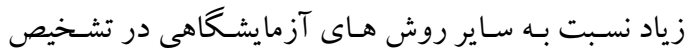
بيمـارى بروسـلوز (IV-19) و بـا توجسه بـه محسـوديتهــاو و معايب روش كشت، بهعنوان استاندارد طلايى در نظر كرفته شده است. در مطالعه حاضر نيـز، آزمـايش PCR بــ آعنـوان آزمايش استاندارد طلايى در نظر كرفته شد. نظر به اينكـه تـاكنون در هـيج مطالعهاى توانـايى آزمايش رزبنگال اصلاح شده و آزمايش الايزا در تشـيص بيمارى بروسلوزمورد مطالعه قرار نخرفته است، لذا هـدف از مطالعه حاضر مقايسه حساسـيت و ويز گیى ايـن دو آزمـايش در تشخيص بيمارى بروسـلوز، در حضـور آزمـايش PCR، بهنوان آزمايش استاندارد طلايى، بود.
مقايسـه نتـايج ايسن دو نـوع ع آزمـايش در نمونسه سـرم افـراد مشكوكك به بروسلوز نشان داد كه نتيجـه ل V9 نمونه سـرم در هر دو آزمايش MRB و الايـزاى IgG مثبـت شـــ و نتيجـه ا9مونه سرم در هر دو آزمايش منفى شـــ. از طرف ديخر تعداد مواردى كه نتيجه الايـزاى IgG در آنهـا منفـى شـد؛ ولى آزمايش رزبنگًال اصلاح شده مثبت گرديـد، سا مـورد

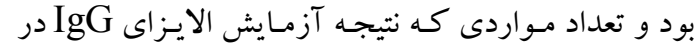
آنها مثبت شد؛ ولى آزمايش رزبنخًال اصـلاح شـده آنهـا

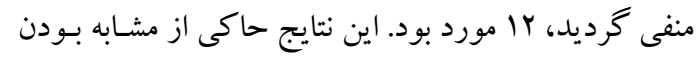

$$
\text { نتيجه اين دو روش آزمايش بود. }
$$

آزما يش رزبنكال اصلاح شده يك آزمايش اسلايدى ساده،

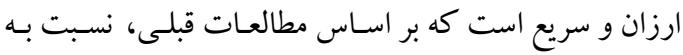

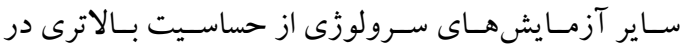


بالاتر باشد، احتمال ابتلا فرد به بيمارى بروسلوز بيشتر اسـت.

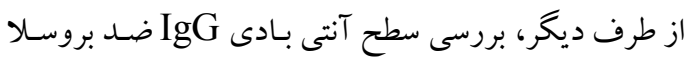
در نمونه سرم بيمـاران مشـكو كك بـه بروسـلوز نشـان داد كـهـ IgG جنانجه مرز مثبت شدن آزمايش الايزا براى آنتىبـادى ضـــ بروسـلا را، بـر اسـاس دسـتور العمل شـركت سـازنده

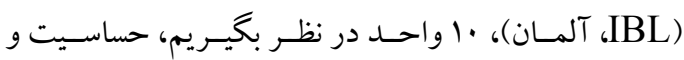

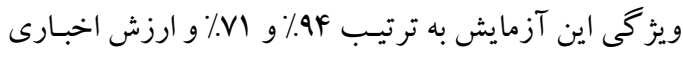

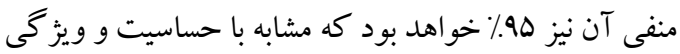
و ارزش اخبارى منفى آزمايش رزبنگال اصلاح شده، است. در موافقت با اين نتايج، فريـرا (Ferreira) و همكـاران نيـز در مطالعه خود به نتيجه مشابهى دست يافتند(·) Gomez

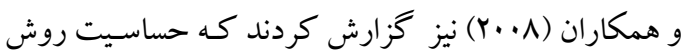
الايزا در تشـخيص بروسـلوز انسـانى بيشـتر از آزمـايشهـاى رزبنخـال و رايـت لولـهاى نيسـت(9). در مطالعـه Ciftçi و همكاران (ه · (Y) در كشور تركيه نيز حساسيت الايـز ابـراى

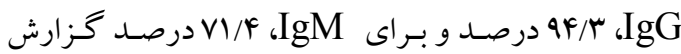
شدهاست(YY)، كه مشابه با نتايج مطالعهه مـا اسـت. همبِنسين

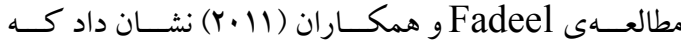
آزمايش الايزا براى IgG حساستر از آزمايش الايـزا بـراى آنتىبادى IgM است(سץ). با اين وجـود در مطالعـ Araj و

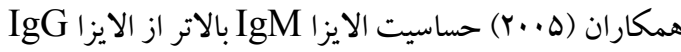
كزارش شده است(YF). متفاوت بـودن نتيجـه مطالعـ Araj مى تواند به ايسن دليـل باشـد كـه بيمـاران شـر كت كنــده در

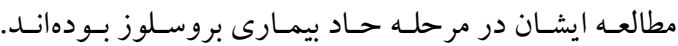
بررسى سـطح IgG در سـرم بيمـاران نشـان داد كـه همانــد آزمايش آكلوتيناسيون استاندارد (SAT)، بين سطح آنتى بادى سرم و احتمال بيمار بودن فرد رابطهى مستقيم وجـود دارد. هر جه سطح آنتى.بـادى IgG بـالاتر باشـد، بـا قطعيـت بيشترى مى توان بر بيمار بودن فرد صحه كذاشـت، هـر جنـــ كاهى ممكن است فردى با سطح آنتىبـادى بـالا نيـز بيمـار نباشد. در اين مطالعه نتيجه آزمـايش الايـزاى IgG بـا نتيجـه آزمايش رزبنگًال اصلاح شده تا 9V٪ تطابق داشت. ايـن امـر حاكى از تطابق بالاى ايـن دو آزمـايش اسـت. در واقع مسى
نتـايج مطالعـه حاضـر نشـان داد كـه حساسـيت و ويز كَى آزمايش رزبنكال اصلاح شده، در حضسور آزمايش PCR

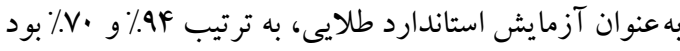

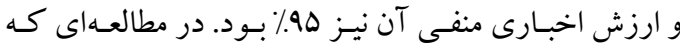

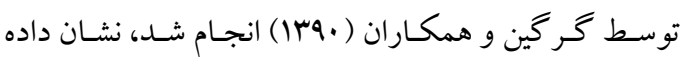
شده است كه آزمايش رزبنگًال اصلاح شده حساسيت بسيار بيشترى نسبت به رزبنگال معمولى و رايت سريع در تشخيص نمونههاى مثبـت از نظر آنتى بـادى ضـد بروسـلا دارد( •().

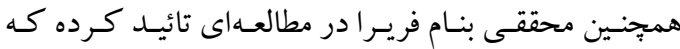
آزمايش رزبنگًال اصلاح شده مى تواند جايكزين سـودمندى براى آزمايش رزبنگال معمولى بـهـ عنـوان آزمـايش غربـالكر

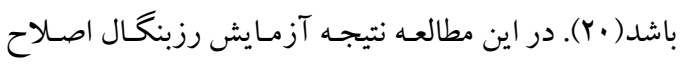
شـده در F مـورد از نمونسههـايى كـه آزمـايش PCR آنهـا مثبـت شـده بودنـد، منفـى گرديــ. نتيجـه منفـى كـاذب در آزمايش رزبنگًال اصلاح شده مىتواند ناشى از يـايين بـودن سطح آنتىبادى در شروع بيمارى بروسلوز، يا ناشى از وجود زير كلاس هاى با خاصيت آكلو تيناسيون بـايين، يـا ناشسى از تيتر بالاى آنتىبـادى (يديـده يـروزون) و يـا اينكـه بـه دليـل بيمارى هايى با عـوارض هيبوايمنو گلوبـولينمى باشـد(سا). از طرف ديخر، در ·س مورد از نمونههـايى كـه نتيجـه آزمـايش رزبنگًال اصلاح شده آن ها مثبت شده بـود، نتيجـه آزمـايش

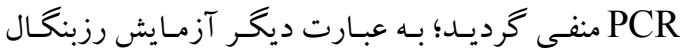
اصلاح شده در آنها بهصورت كاذب مثبت شده بود. نتايج مثبت كاذب در آزمـايش رزبنگـال اصـلاح شـده مسى توانــ ناشى از واكنش متقاطع با عو امل عفونى ديخر مانند باكترى -

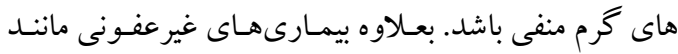
لنفوم، لويوس اريتروماتوز سيسـتميكك و يـا مولتيّل ميولومـا مى توانند سبب واكنش هـاى متقـاطع و مـوارد مثبـت كـاذب

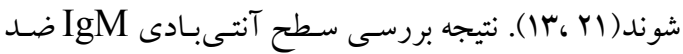
بروسلا در نمونه سرم بيماران مشكو كك به بروسلوز نشان داد كه حساسيت و ويز كى آزمايش الايزا براى آنتىبادى IgM ضد آنتىزنهاى بروسلا به تر تيب 90\% و AK. اسـت. بعـلاوه IgM بر اساس نتايج اين مطالعـه هـر جـه سـطح آنتى بـادى 
IIراسى sقايسم اه هساسيت...

اينكه كيت هاى سنجش آنتىبادى هـاى ضـد بروسـلا اكثراً خـار جى بـوده و متناسـب بـا وضسعيت بيمـارى بروسـلوز در كشور يـا كشـورهـايى تهيـه و استانداردسـازى شـدهانــ كـه متفاوت از شرايط بيمارى بروسلوز در كشـور مـا اسـت، لـذا نمى Cut-off تعيـين شـده در ايسن كيـتهـا را مـلاكك تشخيصى قرار داد. لذا نياز اسـت Cut-off آزمـايش الايـزا

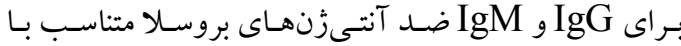
شرايط كشور ما تعيين و استانداردسازى شود.

\section{نتيجه تيرى}

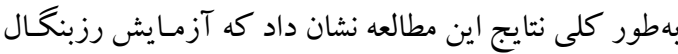
اصلاح شده، يكك آزمايش سـاده، ارزان و سـريع اسـت كـه IgG داراى حساسيت و ويز كَى مشـابه بـا آزمـايش الايـزاى در تشـخيص بيمـارى بروسـلوز اسـت. بـا توجـه بــه اينكـه آزمايش الايزاى IgG، يكك آزمايش كرانقيمت، يِيجيده و

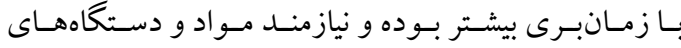
كران قيمت است، لذا با انجام آزمايش رزبنگًال اصلاح شده مىتوان نياز به آزمايش الايزا را مرتفع ساخت.

تشكر و قدردانى

نويسندگان مقاله مراتب قدردانى خود را از معاونت تحقيقات و فن آورى دانشگاه علوم زيزشكى كرمانشاه بواسطه تامين هزينه انجام اين طرح بثزوهشى اعلام مىدارند. اين مقاله حاصل ياياننامه كارشناسى ارشد آقاى بهروز هلشى است كه در قالب يك طرح تحقيقاتى با كد رهكيرى 94.9V و با كد اخلاق:1394.518) ثبت شده است. بودجه اين طرح توسط معاونت تحقيقات و فن آورى دانشگاه علوم يزشكى كرمانشاه تامين گرديد.
تـوان كفـت كـه مزيــت الايـزاى IgG نسـبت بـه رزبنـــال اصلاح شده، تعيين هم زمان نمونههاى مثبت و سـطح آنتى بادى IgG در اين نمونهها است. در حسالى كـه در آزمايش رزبنگكال اصلاح شده، تنهـا مسى تـوان نمونسهــاى مثـت و تـا حدى شدت مثبت شدن آن ها را مشخص ساخت؛ امـا بـراى تعيين تيتـر آنتسىبـادى نيـاز بـه آزمـايشهـاى تكميلى مانــــ آزمايش SAT است؛ بنابراين، بر اساس نتـايج ايـن مطالعه، مى توان آزمايش رزبنشال اصـلاح شـده كـه يـك آزمـايش

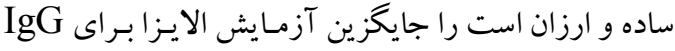

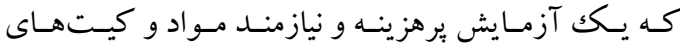
آزما يشگاهى و دستخاههاى كرانقيمت اسـت، كرد. بـا ايسن وجود، در اين مطالعه نتيجه آزمايش رزبنخَال اصـلاح شـده در دو نمونسه سـرمى كـه نتيجـه آزمـايش الايـزا IgG آنهـا مثبـت شـده و سـطح آنتـىبـادى بـالايى نشـان دادنـد، منفى كرديد. ايـن امـر مسىتوانـد ناشىى از وجـود آنتىبـادىهـاى غير آكلو تينان در اين نمونه سرمها باشد. جرا كه اين دسته از آنتىبادى ها در حالى كه با آزمايش رزبنگَـال اصـلاح شـده قابل تشخيص نيستند، با آزمـايش الايـزا بـه خـوبى تشـخيص داده مىشوند و اين يكى از امتيازهاى آزمايش الايزا نسـبت به آزمايش هاى مبتنى بر آكلوتيناسيون محسوب مى شود. نظر به اينكه بيمارى بروسلوز در كشور ما اندميك است، لذا همواره سطح يايينى از آنتىبادى در سرم برخى افراد وجـود دارد. براى حذف يا كاهش موارد مثبت كاذب در آزمـايش الايزاى IgG، بايستى Cut-off بـالاترى را بـهنــوان معيـار

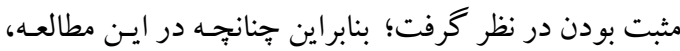
مرز مثبت شدن آزمـايش الايـزا بـراى IgG ضــد بروسـلا را

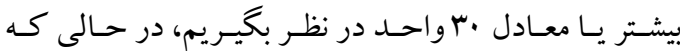

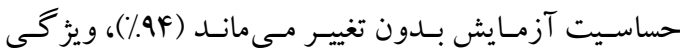

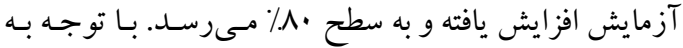

منابع

1. Cutler S, Whatmore A. Progress in understanding brucellosis. Vet Rec. 2003; 153(21):6412 .

2. Seleem MN, Boyle SM, Sriranganathan N. Brucellosis: a re-emerging zoonosis. Vet Microbiol. 2010; 140(3-4):392-8. 
IN على كرين كرجى

3. Pappas G, Akritidis N, Bosilkovski M, Tsianos E. Brucellosis. N Engl J Med. 2005; 352(22):2325-36.

4. Young EJ. An overview of human brucellosis. Clin Infect Dis. 1995; 21(2):283-9.

5. Irmak H, Buzgan T, Evirgen O, Akdeniz H, Demiroz AP, Abdoel TH, et al. Use of the Brucella IgM and IgG flow assays in the serodiagnosis of human brucellosis in an area endemic for brucellosis. Am J Trop Med Hyg. 2004; 70(6):688-94.

6. Mangalgi S, Sajjan A. Comparison of three blood culture techniques in the diagnosis of human brucellosis. J Lab Physicians. 2014; 6(1):14-7.

7. Marei A, Boghdadi G, Abdel-Hamed N, Hessin R, Abdoel T, Smits H, et al. Laboratory diagnosis of human brucellosis in Egypt and persistence of the pathogen following treatment. J Infect Dev Ctries. 2011; 5(11):786-91.

8. Araj GF. Update on laboratory diagnosis of human brucellosis. Int J Antimicrob Agents. 2010; 36 Suppl 1: S12-7.

9. Gomez MC, Nieto JA, Rosa C, Geijo P, Escribano MA, Munoz A, et al. Evaluation of seven tests for diagnosis of human brucellosis in an area where the disease is endemic. Clin Vaccine Immunol. 2008; 15(6):1031-3.

10. Gorgin Karaji A, Abdi F, Rezaei M. The agreement rate of rose Bengal, modified rose Bengal and rapid Wright tests for detection of positive serum sample of Brucellosis. Behbood Journal. 2011; 15(1):31-9.

11. Blasco JM, Garin-Bastuji B, Marin CM, Gerbier G, Fanlo J, Jimenez de Bagues MP, et al. Efficacy of different Rose Bengal and complement fixation antigens for the diagnosis of Brucella melitensis infection in sheep and goats. Vet Rec. 1994; 134(16):415-20.

12. Emmerzaal A, de Wit JJ, Dijkstra T, Bakker D, van Zijderveld FG. The Dutch Brucella abortus monitoring programme for cattle: the impact of false-positive serological reactions and comparison of serological tests. Vet Q. 2002; 24(1):40-6.

13. Shirzadi MR, Zinali M, Rezaei F. Guide to Diagnosis and Treatment of Brucellosis (Malta fever). In: Office for the Prevention of Human - Animal Communicable Diseases, Deputy of Health, Ministry of Health and Medical Education, 2014:1-116.

14. Imaoka K, Kimura M, Suzuki M, Kamiyama T, Yamada A. Simultaneous detection of the genus Brucella by combinatorial PCR. Jpn J Infect Dis. 2007; 60(2-3):137-9.

15. Hekmatimoghaddam S, Sadeh M, Khalili MB, Mollaabedin M, Sazmand A. Comparison of PCR, Wright agglutination test and blood culture for diagnosis of brucellosis in suspected patients. Pak J Biol Sci. 2013; 16(22):1589-92.

16. Queipo-Ortuno MI, Morata P, Ocon P, Manchado P, Colmenero JD. Rapid diagnosis of human brucellosis by peripheral-blood PCR assay. J Clin Microbiol. 1997; 35(11):2927-30.

17. Al-Attas RA, Al-Khalifa M, Al-Qurashi AR, Badawy M, Al-Gualy N. Evaluation of PCR, culture and serology for the diagnosis of acute human brucellosis. Ann Saudi Med. $2000 ; 20(3-4): 224-8$.

18. Elfaki MG, Al-Hokail AA, Nakeeb SM, Al-Rabiah FA. Evaluation of culture, tube agglutination, and PCR methods for the diagnosis of brucellosis in humans. Med Sci Monit. 2005; 11(11):69-74.

19. El Kholy AA, Gomaa HE, El Anany MG, Abd El Rasheed E. Diagnosis of human brucellosis in Egypt by polymerase chain reaction. East Mediterr Health J. 2009; 15(5):106874.

20. Ferreira AC, Cardoso R, Travassos Dias I, Mariano I, Belo A, Rolao Preto I, et al. Evaluation of a modified Rose Bengal test and an indirect enzyme-linked immunosorbent assay for the diagnosis of Brucella melitensis infection in sheep. Vet Res. 2003; 34(3):297305.

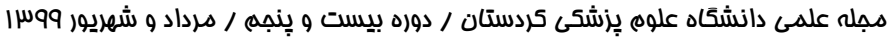


21. E. BJ, J. BM, Raphael D. Principles and Practice of infectious Diseases. Brucella Species. 6th ed ed. New Yourk: Churchill Living Stome; 2005.

22. Ciftci C, Ozturk F, Oztekin A, Karaoglan H, Saba R, Gultekin M, et al. Comparison of the serological tests used for the laboratory diagnosis of brucellosis. Mikrobiyol Bul. 2005; 39(3):291-9.

23. Fadeel MA, Hoffmaster AR, Shi J, Pimentel G, Stoddard RA. Comparison of four commercial IgM and IgG ELISA kits for diagnosing brucellosis. J Med Microbiol. 2011; 60(12):1767-73.

24. Araj GF, Kattar MM, Fattouh LG, Bajakian KO, Kobeissi SA. Evaluation of the PANBIO Brucella immunoglobulin $\mathrm{G}$ (IgG) and IgM enzyme-linked immunosorbent assays for diagnosis of human brucellosis. Clin Diagn Lab Immunol. 2005; 12(11):1334-5. 